\title{
Role of (Local) Culture in English Language Teaching
}

\author{
Kumar Shrestha
}

\begin{abstract}
Since language and culture have muscle and bone relationship, the existence of one in the absence of another in unthinkable. But in practice, English language teaching has paid less attention to the local culture. It is commonly believed that the insertion of foreign cultural values is not in line with local cultural values. The insertion of local culture plays vital role in promotion of nationalism, different local cultures and local cultural wisdom. Similarly, it provides cultural identity and meaningful context for learning. Therefore, the main purpose of this article is to shed light on the importance of local culture in the English language classroom. In doing so, it aims at defining culture, language, shows relationship between them and puts forth some pedagogical guidelines.
\end{abstract}

Key words: Culture, native culture, foreign culture, language

\section{Introduction}

English is spoken all over the world. The spread of the English language began in the period of European colonization i.e. from the $16^{\text {th }}$ century to the mid- $20^{\text {th }}$ century. It eventually privileged the economic and political power of English speaking countries, especially Britain and America. English has been used for different purposes all over the world such as education, science and technology, commerce and tourism. The English language spread all over the world massively because of the fast pace of globalization. "This has helped them achieve the recognition of their identity from the global community and they are reciprocated by the knowledge and power" (Bhattarai \& Gautam, 2008, p. 11). But, while teaching English as a target language
(TL) or foreign language (FL), a question arises whether to teach 'target language only', or 'target language and target culture, or 'target language and local culture' and so on.

The dialectical connection between language and culture has posed a challenge to the teachers and educators. Broadly, the issue of teaching culture with the English language can be categorized under four different views. They are:

1. Target language culture with English

2. No target language culture with English

3. Local culture with English, and

4. Culture free English. 
The first group of scholars believe that 'target language culture' should be taught with English to acculturate learners into the English communities (Byram 1997, Byram \& Flemming 1998, as cited in Choudhury 2014). The second group of scholars opine that there should not be any teaching of the 'target language culture' with English in the countries where English is an institutionalized variety (Kachru 1986, Kachru \& Nelson 1996, Canagarajah1999, as cited in Choudhury 2014). Similarly, the third view supports the teaching of local culture to facilitate foreign language learning (Kramch \& Sullivan 1996, McKay 2003 as cited in Choudhury 2014). Lastly, the fourth group of scholars advocate that English has become a lingua franca, therefore, it should be taught in a culture-free way (Alptekin 2005, Jenkins 2005, Seidlhofer 2001, as cited in Choudhury 2014). These arguments, in for and against the teaching of culture, show that language comes with culture. In other words, language and culture are correlated and culture has roles to play in teaching language.

\section{Culture and language}

Culture is the way of life of people who share it. It can be everything like language, religion, costume, food habits, social habits, music and arts. At first, Taylor (1871) defined culture as "that complex whole which includes knowledge, belief, art, law, morals, custom and other capabilities and habits acquired by man as a member of society" (1). Culture is the way of thinking and understanding the world and our own life also. It can vary within a country, region, and society, sub-group and within a family as well. Culture is a crucial tool for survival too. Furthermore, culture is a civilization in itself since it is connected with the origin of people.

People not only use language as a means of communication, but they also express their values, belief and world views through it.
"When a language becomes extinct, a part of the cultural patrimony of humanity is lost" (Barfield \& Uzarski 2009, p.2). In this regard, culture is a typical and a common identity of the people of the group who share the same world view. But it is a fragile phenomenon too since it is constantly changing and easily lost as it exists only in our mind. Since culture comprises language as its part and it finds its survival in the expression of language, it can be said that culture and language are intricately interwoven. Language has two roles: as a means of communication and a carrier of culture. Therefore, a particular language is a mirror of a particular culture.

\section{Significance of local culture in English language teaching}

Generally, native culture of the foreign language learners can be understood as 'indigenous culture' or 'local culture' though the two terms have slightly different connotations. The indigenous culture generally refers to the culture of indigenous people of a land employed for centuries for survival and everyday existence (Kramsch, 2011). Local culture refers to the culture of local people who have lived in a particular place for a period of time. These both can be the source of native culture while teaching foreign language because both can be sources of knowledge and can influence the language learners. Thus, throughout this article the author will use these terms interchangeably.

It is quite straightforward that teaching a language means teaching its culture too. The interdependence of language learning and culture learning is so evident that one can conclude that language learning is culture learning, and language teaching is cultural teaching (Goa, 2006 as cited in Choudhury 2014). Learning and teaching foreign language remains incomplete until and unless the learners learn culture 
belonging to the language. Stressing the reality of foreign language teaching, Wang (2008, as cited in Choudhurry 2014, p. 3) asserts, "Foreign language teaching is foreign culture teaching and foreign language teachers are foreign culture teachers". However, here arises a question whether foreign culture is enough to teach foreign language or not. What happens when the native (indigenous and/or local) culture of the learner is neglected while teaching a foreign language? For example, Sun (2007, as cited in Neff \& Rucynsi 2013, p. 12) mentions that when a Chinese speaker asks "Have you eaten supper?", it is a conversation starter rather than a question regarding someone's eating habits. Similarly, in Nepali speaking community also, asking "Have you taken tea?" is not a question. Not knowing these sorts of cultural titbits may cause problem in communication. Therefore, "in order to truly communicate effectively, the students of a foreign language need both linguistic and intercultural competence" (Neff \& Rucynski 2013, p. 13). In this regard, a language teacher should be aware of both local culture, target culture and their norms and values. Along with target culture, s/ he needs to integrate local culture and its norms and values in the foreign language classroom. Stressing on the need for local culture, Sudartini (2012) opines that the underlying reason of inserting local culture is for the sake of national identity. In this regard, local culture is local wisdom that promotes character education as well as assures national identity. The insertion of the local cultural values can be a way of preparing the learners' cultural background and identity that ultimately forms nationalism in their mind. Therefore, the sole emphasis on TL and target culture makes foreign language learning incomplete and handicapped. Highlighting the importance of native culture, Barfield and Uzarski (2009) say "integrating local indigenous culture into English language learning not only educates learners about indigenous people in their own countries and through the world; it also makes learning English more relevant for indigenous students in those classrooms" (p. 2). Here local culture does not mean the culture of the foreign language learners only; it may mean the culture of his or her neighbouring regions. For example, Nepali speakers learning the English language can be taught through Maithili culture, Newari culture, and so on. These local or neighbouring cultures not only enhance their foreign language learning process, but also expand their knowledge of indigenous cultures. It evidently shows the need for employing the local culture along with foreign culture while learning a foreign language.

Teaching the local culture does not negate the value of teaching the target culture. Kramsch (1993) argues that a foreign culture and one's own culture should be placed together in order for learner to understand a foreign culture. Learners cannot fully derive the meaning in the absence of foreign culture. Similarly, local culture is necessary to construct their own meaning. It promotes the understanding of learners. On top of that, if the learners talk with the foreigner, the foreign culture and language is alright but if they talk about the local context in foreign language, the local culture is a must. Integration of native culture of the learners also helps promote the culture of learners. Showing the relationship between indigenous culture and foreign language, Barfield and Uzarski (2009) state:

Interestingly, despite the loss or future loss of an indigenous language, the 'roots' of that indigenous culture can be preserved through the learning of another language, such as English; just as the proper physical elements (sun, water, nutrients) allow prairie to regrow, linguistic and cultural 
elements can be revived and reborn as well" (p. 8).

\section{Guidelines for teaching (native) culture}

It is difficult to address a cultural issue in language classroom. It is challenging for teachers to have proficiency in target culture, TL, native culture and ways of teaching them. Byrnes (2008, as cited in Frank 2013) says many EFL teachers have had no formal training in incorporating cultural elements, and there is no universally accepted set of criteria that instructors can use as a guide. It demands research and renovation in the field of teaching cultural elements in foreign language classroom. Since the need of teaching native culture along with foreign culture appeared in the surface of ELT, different approaches have appeared on the surface. Choudhury (2014) claims that learners' own culture is not dealt with as an abstract concept; they need be involved in it. He further says learners are encouraged to reflect their cultural experience in TL. It provides easy matters to express in the TL. It also raises the questions regarding which culture we need to teach first - whether the target culture or native culture. But it seems easy to begin with local one since the learners have its wider ideas. Byram (1997) urges teachers to start by reflecting on learners' own culture and only later introduce the target culture. The similarity between these two cultures can also help the learners to construct a mental framework and learn TL titbits.

When the manner of teaching (pedagogy) comes, there comes the matter of teaching (contents) also. In this regard, Bodley (1994) states that culture is "what people think, make, and do" (p.22). For Bodley culture is a socially transmitted set of common belief that comprises mental behaviour, physical concretization of mental behaviour and a framework for society to guide the way of doing. Therefore, the teacher can also make their students think what people 'think, make and do'. Teachers can make their students think about etiquette and manner, food and cuisine, religion, music, customs and traditions, etc. On top of this, teachers can ask their students to relate these practices of society with real life of the local people. Discussion of uniqueness of cultures, set values and beliefs, and their important aspects can make class lively and interesting. Regarding the 'what' aspect of culture teaching, Frank (2013) suggests, "Teachers need to go beyond introducing traditional holidays, food, and folk songs of the target culture and incorporate a framework that enables students to understand the social aspects of the culture as well" (p. 11). So, to provide comprehensive knowledge of culture, the teachers need to incorporate social norms, values, belief and other such practices in the classroom activates.

The Standards for Foreign Language Learning (NSFLEP, 1999 as cited in Frank 2013, p.3) has provided a framework for students to integrate "the philosophical perspectives, the behavioural practices, and the products-both tangible and intangible-of the society". Frank has presented this idea as the 3P model of culture that includes: (a) Perspectives (what members of a culture think, feel and value); (b) Practices(how members communicate and interact with one another); (c) Products(technology, music, art, food, literature, etc.; the things members of a group create, share, and transmit to the next generation).

Here, the idea of Bodley (1994) 'think, make and do' seems similar to this. It is very difficult to recognize perspectives and practices since they are deep-rooted in the society. The product part of society is easy to indentify through our sense organs. 
Renaud and Tannenbaum (2013) have suggested four levels of cultural awareness. They believe that "cultural awareness is advanced through mutual reflection and interaction at four levels: (1) self, (2) family, (3) community, and (4) the region and world at large" (p. 25). Figure 1 below shows their concept vividly.

Figure1: Four levels of cultural awareness (Source: Renaud \& Tannenbaum 2013, p. 25)

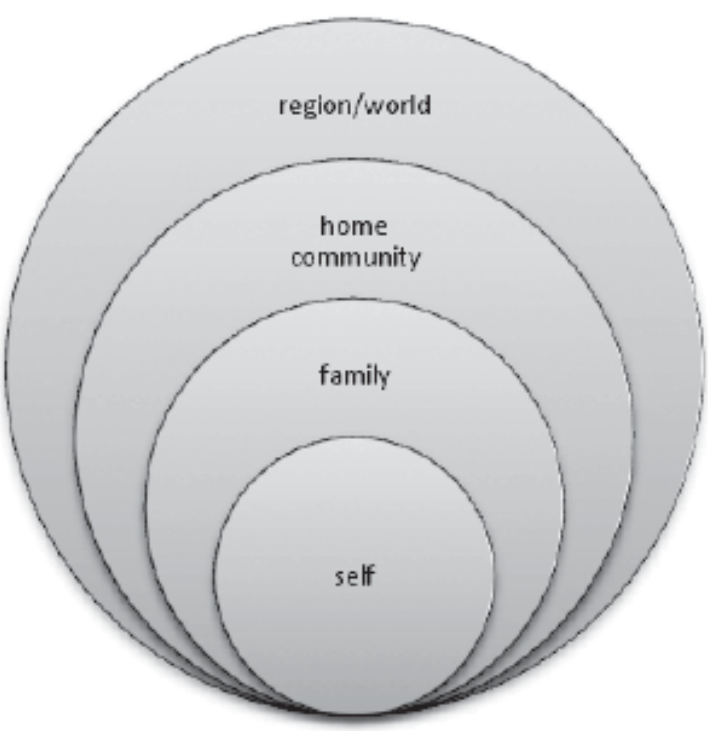

We feel comfortable with the culture and language of neighbouring areas. For example, if Nepalese students read any story from India, they feel and understand it very well. It is because there are cultural similarities, geographical proximity and even linguistic resemblance. The case cannot be same with any other British and American stories for Nepalese students. Thus, cultural, geographical and linguistic proximity also matter while learning foreign language and culture. Let's observe the level of cultural learning put forth by Renaud and Tannenbaum (2013) as discussed below.

\section{Level 1 and 2: Self and family}

All people are members of at least one culture. Their culture affects how they think, interact, communicate and transmit knowledge from one generation to another. Therefore, in classroom, teachers should provide opportunities for students to talk about themselves and their families in TL. In a multicultural country like Nepal, sharing information about themselves with the peers brings diversity in the contents of the classroom along with cultural and linguistic tolerance. It also encourages the students to speak in the class in TL. At this level, teachers can encourage their learners to talk about their own and their family's likes and dislikes regarding food habit, music, sports, dress, work and duties, etc. using their TL.

\section{Level 3: Community}

At this level, the students begin to relate themselves to the community in the classroom and the larger community around. Classroom in Nepal is like a community in itself since it embraces heterogeneous groups of students. Here, it is very difficult to find all students from mono-cultural and mono-linguistic background. Thus, the teachers can instigate the students to talk about their indigenous patterns of behaviour, values, belief, costumes, etiquette and manners, music etc. What differs in this level is it provides students with the opportunities to talk about their community in TL? On top of this, they share their ideas; may be the same ideas they practice at level 1 and 2 in pair and group also, and then with the whole class. Interview with the peer, telling stories that originate from the learners' shared personal experience (Language Experience Approach, Renaud \& Tannenbaum 2013, p. 28) in the class are some of the techniques that teachers can use in the classroom. 


\section{Level 4: Region/world}

Finally, students extend their cultural awareness as the participants of a larger region and the world. It helps them to find their identity and a sense of shared responsibility as citizens of the larger region. It enables them to extend their cultural knowledge and the knowledge of the world. It makes their language use flexible and versatile. This level can be taken as the threshold level between local and foreign cultures. At this level, the students not only talk about their own culture but also about foreign culture using TL. This level also shows the necessity of the local culture in foreign language learning.

The main aim of teaching culture in language classroom is to make students' intercultural communication possible. Byram (1997) suggests that interculturally competent people have a solid understanding of their own culture and how it has shaped them, and make connections between how cultural elements manifest in behaviour across cultures. For Byram, interculturally competent people are open and curious to other culture. They have the ability to critically evaluate the cultural practices and products of one's own culture and that of other countries. At this level, the students should have clear understanding of their own culture and the target culture. If so, they can make their culture comprehensible to the foreign language community. Similarly, they can make foreign culture comprehensible to their own community too.

\section{Conclusion}

Owing the inseparable relation between language and culture, teaching language is impossible without teaching its culture. It is widely known that the common practice of English language teaching has been focused for preparing the students to be able to communicate effectively. On top of this, the students are also learning English culture. Although integrating English culture while teaching English is the necessary devil, teachers are rarely integrating local culture in it. Though further research should be carried out to know that fact, it can be inferred that the absence of local culture in foreign language classroom has created two problems. The first one is that the learners' foreign language competency remains incomplete. As different cultures may have something in common, the process of comparison and contrast can be an analytical tool to get mastery over the target culture/TL. Similarly, since TL learners already have a layer of world knowledge, sometimes the learners have to unlearn their previous knowledge and relearn new things. Their previous world view may have no roles or limited roles to play in learning TL. It can make their learning process slow and complex. The next thing is that it can make the students forget their own culture and adopt foreign culture as their own that can ultimately cause disappearance of culture and language. Therefore, keeping these facts in mind, all the teachers involved in foreign language teaching need to integrate the local culture while teaching foreign culture. However, caution is necessary while designing curriculum and teaching FL as this may inadvertently promote nationalism or ethnocentric view of the foreign language and culture. A delicate balance in the curriculum design and teaching learning process is required to ensure neither culture erodes the values of the other.

English is taught as an international language and/or lingua franca. Because of its wider use and popularity, it is unavoidable in our daily life. There are other ways round of using the English language. First of all, it can be considered that indigenous and local culture triggers 
the learning process of foreign language by facilitating learning process. Proper use of cultural contents creates intercultural tolerance in the class, ultimately in the society too. It can also be a means to protect and promote indigenous and local language and culture. Similarly, insertion of indigenous and local culture preserves and promotes learners' cultural values and typical identities. It ultimately preserves their nationalistic feeling which is also one of the characters of educational goals.

\section{References}

Barfield, S. \& Uzarski, J. (2009). Integrating indigenous cultures into English language teaching. English Teaching Forum, 47 (1), 2-9.

Bhattarai, G.R. \& Gautam, G.R. (2008). More eclectic and interdisciplinary approach to English: Call of time. Journal of NELTA, 13 (1-2), 11-14.

Bodley, J.H. (1994). Cultural anthropology: Tribe, states, and the global system. Palo Alto, CA: Mayfield.

Byram, M. (1997). Teaching and assessing intercultural communicative competence. Clevedon, UK: Multilingual Matters.

Choudhury, R.U. (2014). The role of culture in teaching and learning of English as a foreign language. Express, an International Journal of multidisciplinary research, 1 (4), $1-20$.

Die, G.S. (2011). Integrating local cultural knowledge as formal and informal education for young African learners: A Ghanaian case study. Canadian and International Education/Education canadienne et internatonale, 40 (1), 20-40.
Frank, J. (2013). Raising cultural awareness in English language classroom. English Teaching Forum, 51 (4), 2-35.

Kramsch, C. (1993). Context and culture in language teaching. Oxford: Oxford University Press.

Neff, P. \& Rucynski, J.J. (2013). Tasks for integrating language and culture teaching. English Teaching Forum, 51 (2), 12-23.

Renaud, S. and Tannenbaum, E. (2013). Making connections: Language activities for creating interpersonal tolerance in the class. English Teaching Forum, 51(2), 24-31.

Sudartini, S. (2012). Inserting local culture in English language teaching to promote character education. Journal Pendidikan Karakter, 2 (1), 45-54.

Taylor, E.B. (1871). Islam and Culture. London: Cape.

The author: Kumar Narayan Shrestha, M.Ed. and M.A., is a faculty at T.U. and K.U., Nepal. He is an M.Phil. scholar at K.U. He has been associated with the field of teaching for seventeen years. He has published articles in different journals and presented papers in national/ international conferences. His professional interests include ELT, research and translation. 